Congress talks tough \section{and basic research}

[WASHINGTON] Science lobbyists in the United States face a tough battle this summer to restore research funding at the space agency NASA and at the National Science Foundation (NSF). The House of Representatives' Appropriations Committee has proposed a bill that would slash NASA's budget by almost $\$ 1$ billion and freeze spending at the NSF.

Efforts will be made to restore some of the NASA spending this week, when the Republican-controlled House tries to pass the broad budget bill that covers Veterans' Affairs and Housing and Urban Development (VA-HUD) and independent agencies, which includes funding for the NSF and NASA.

A spokesman for Jim Sensenbrenner (Republican, Wisconsin), chairman of the House Science Committee, said he was "trying to ensure that some of the funds were restored" before the House votes on the bill.

The version of the bill passed by the Appropriations Committee last week proposed huge cuts in research at NASA. The bill would reduce the space agency's total budget from $\$ 13.7$ billion to $\$ 12.7$ billion, and cut space science by $\$ 240$ million and Earth science by $\$ 285$ million.

The committee voted to restore $\$ 400$ million worth of cuts - including the cancellation of the Space Infrared Telescope Facility project - which had earlier been endorsed by its VA-HUD subcommittee.

The bill would also hold the NSF's budget at its 1999 level of $\$ 3.65$ billion, denying a request from the Clinton administration for a 6 per cent increase. The version would grant only $\$ 35$ million of the $\$ 146$ million that the administration requested for a new information technology research initiative.

Agency heads moved quickly to attack the proposals. "Not only is this cut devastating to NASA's programmes, it is a knife in the heart of employee morale," said NASA administrator Dan Goldin. NSF director Rita Colwell said in a statement: "We're ready to do twenty-first century science and engineering, but we can't do it on a twentieth-century budget."

But the cuts proposed in the House VAHUD bill are a long way from being implemented. They reflect the low budget allocation granted to the bill to keep spending under the tight budget caps agreed by the Congress and the administration in 1997.

The cuts proposed for NASA's Earth sciences programme will be bitterly opposed by influential senators such as Barbara Mikulski (Democrat, Maryland), whose state is home to the Goddard Space Center. The White House also said it would veto the bill on various grounds, including its funding levels for NASA and the NSF.

Colin Macilwain

\title{
BSE advisers admit giving up a purely scientific role
}

[LONDON] Scientists advising the British government on the outbreak of the bovine spongiform encephalopathy (BSE) epidemic in the late 1980s claim that they came under pressure from officials to endorse a statement on the safety of beef. They also admit they were uncomfortable about their relationship with civil servants and ministers.

The admissions emerged last week during the questioning of members of the Spongiform Encephalopathy Advisory Committee (SEAC), at the public inquiry headed by Lord Phillips.

SEAC has handled advice to the government on the epidemic since 1990. It was supposed to stand back from immediate issues and focus on underlying science, but this goal appears to have been compromised only two-and-a-half weeks after it first met.

SEAC members were contacted by the Chief Medical Officer (CMO) on 16 May 1990 and asked to approve a statement he was issuing the following day saying that beef was safe. David Tyrrell, who headed SEAC at the time, said its members had felt uncomfortable and anxious about having to approve a statement at such short notice.

At the inquiry, SEAC members were questioned on the committee's close working relationship with the government. They said that a shortage of time to deal with pressing problems and a shortage of technical expertise had left SEAC working closely with the Ministry of Agriculture, Fisheries and Food (MAFF).

Phillips and others conducting the questioning also expressed interest in the way that the government's CMO was kept closely informed of SEAC's deliberations by Hilary
Pickles, a member of the committee's secretariat provided by the Department of Health.

Pickles drafted material for SEAC, as well as for an earlier scientific committee advising the government on the BSE outbreak (see Nature 400, 389; 1999). Pickles put together material for the CMO's appearance in front of a government committee - and this later formed the basis of SEAC advice to the CMO.

It emerged that the draft SEAC report was also circulated to MAFF officials for comment. Asked whether he saw a possible conflict in the fact that departments expecting advice were contributing to it, Tyrrell said, "We had already sold the pass, having said we are going to be involved in doing things to help a CMO".

He added: "We had given up the idea of trying to stand back and do nothing else but evaluate science at a distance and impartially."

Tyrrell later rephrased his words, saying the committee members would have picked up changes to the document that they disagreed with. But he admitted to being worried about dropping from their advice the phrase: "No scientist would say there was no risk of eating beef". MAFF officials felt that certain statements were inflammatory, said Tyrrell, and were worried about public reaction.

Asked if the draft paper should have been subjected to this kind of process, Tyrrell said that with hindsight and in an ideal world this should not have happened. He would defend the situation at the time, however, "by saying it was so fraught, almost that we had to do something, or at least it was seen by those in the ministry that we had to do something and get it out soon".

NatashaLoder

\section{UN call for action to clear up space junk}

[MUNICH] Member states of the United

Nations (UN) have been asked to take steps to increase awareness of the potential impact of space activities on science, and on the economic development of rich and poor nations. Such steps should include exploring the legal aspects of space debris, and protecting some regions of the Earth from radio emissions.

The recommendations are included in the Vienna Declaration on Space and Human Development and a related action plan that were approved last week at the end of the third UN Conference on the Exploration and Peaceful Uses of Outer Space - UNISPACE III - held in Vienna, Austria.

Those attending the conference also urged the creation of a voluntary $\mathrm{UN}$ fund to translate the recommendations into action. The two-week meeting was the first UN space conference since 1982 . In its technical forums, astronomers expressed serious concern that light pollution, radio interference and space debris are endangering their research.

The delegates recommended holding international meetings of researchers on near-Earth objects, organized by the UN Officer for Outer Space Affairs. They also called for the creation of an international space authority to facilitate cooperation on space debris. This organization should also coordinate the detection of landmines from space, and develop legal frameworks.

The declaration stresses that Third World countries must not be excluded from the benefits of space science. Eva von Schaper 